\title{
Local Government Structure and Capacities in Europe
}

\author{
Juraj Nemec \\ Masaryk University, Brno, Czech Republic \\ Michiel S de Vries \\ Radboud University Nijmegen Institute of Management Research, Netherlands and \\ Masaryk University, Brno, Czech Republic \\ cross $^{\text {ref }}$ http://dx.doi.org/10.5755/j01.ppaa.14.3.13434
}

\begin{abstract}
This article argues that the local government capacities and local government performance in Europe clearly rank this continent to the most developed world areas from the point of local democracy. The background factors explaining this situation have a multidimensional character and one can identify as core positive factors the relative economic wealth, high human development, the long historical tradition of the subsidiarity principle in most parts of Europe, and the regulatory function of the Council of Europe. The strong development of local and regional democracy in Europe is protected and based on the principles of European Charter of Local Self Government. However, this does not mean that everything is perfect in Europe and that there would be no challenges to be addressed. It is difficult to define clear common weaknesses of the local democracy in Europe. We need to mention the core structural challenges here, for instance the continuous discussion about amalgamation versus fragmentation. Most countries also indicate one overarching threat to the local democracy in Europe today, that is, the financial crisis, which significantly decreased the level of available financial resources for selfgovernments, while the structure of responsibilities remains the same or even increases. Another core threat visible in many European countries is the trend toward re-centralization or limited real will do continue with decentralization in, both in established and emerging democracies. Regional issues differ, and we mention especially the situation of post-communist countries, where local democracy does not have a long tradition and still needs to be revitalized.
\end{abstract}

Keywords: European Union, Council of Europe, European Charter of Local Self Government, decentralization, local finance, fragmentation.

Raktažodžiai: Europos Sajunga, Europos Taryba, Europos vietos savivaldos chartija, decentralizacija, vietos valdžios finansai, fragmentacija. 


\section{Introduction}

Europe consists of 51 states on the World's second smallest continent. Of these 51 states, 47 belong to the Council of Europe, which thus comprises the most comprehensive common structure for European countries (COE - www.coe.int) covering 800 million citizens (Belorussia territorially belongs to this area, but is not accepted to the organization, and San Marino, Kosovo and Vatican city are also not a member of the Council).

The unifying governance structure for members of the Council of Europe, related to our topic, is the existence of specific regulations concerning the rights and roles of local governments - the existence, ratification and enforcement of the European Charter of Local Self-government (Charter - the detailed analysis of the contents of the Charter will be provided by the later text). Council of Europe members delegate their representatives to the Congress of Local and Regional Authorities (Congress/CLRAE). CLRAE was established in 1994 to act as the voice of Europe's regions and municipalities in the Council of Europe. It provides a forum to allow for local and regional elected representatives to effectively participate at a European level. The Congress consists of both a Chamber of Regions and a Chamber of Local Authorities. The role of this Congress in Europe is not marginal - between many tools to protect interests of local and regional authorities, the Congress organizes regular monitoring visits to all Council of Europe member states with the aim to evaluate the "quality" of local and regional democracy. Recommendations from such visits are normally well respected by member states. Reports from monitoring visits are publicly available via Congress web pages and represent one of main sources for this article. This Congress provides the basic legal structure for the functioning of local government, to which all member-states adhered.

The existence of such a forum does not imply that the members are alike. As will be argued below, Europe is not at all the homogeneous area with regard to governance structures, people outside Europe might think it is. The goal of this article is to present and discuss the context and problems of, and trends in local governance in Europe. We first introduce the main lines of division in historical, political, economic and legal terms. This gives the varying contexts in which local governments on this continent have to function. Second, the capacity of local governments is assessed, and third this article addresses some recent trends in Europe to improve the capacity of local governments.

\section{The Varying Context of Local Government in Europe}

This section addresses some of the main lines of divisions within Europe important for the position of local government. First we address national differences and secondly general and institutional differences directly related to local government. 


\section{National Differences}

The first and most visible line is that of the European Union consisting of 28 of the 51 European states. The EU is important for the functioning of local government, because it adheres to the principle of subsidiarity, the organizing principle of decentralization, implying that decisions are to be taken as closely as possible to the citizens. This is laid down in Article 5 of the treaty of the European Union.

This brings us to the second line of division, partly overlapping with the division between EU and non-EU members, which is the wealth of countries. With regard to the wealth of nations, the Council of Europe consists of highly developed countries (OECD data), located especially in the west and northwest of it (Luxembourg and Lichtenstein have incomes of over 100000 USD per capita). On the other hand, several developing countries also belong to this continent, too, located especially in the east (Moldova being the poorest with an income of about 1500 USD per capita).

The third line important also for local governments is the Human Development Index, comprising education, health and living standards [17]. One can distinguish the European countries also in this respect. There are seven countries with almost maximum scores $(>0.90)$ on the Human Development Index. These are Norway, Sweden, Switzerland, Iceland, Ireland, Germany and the Netherlands. All other countries belonging to the EU have very high HDI-scores (0.80-0.90). Non-EU members have high scores between 0.70 and 0.80 , and the one poor member of the European family, that is Moldova, still has a medium HDI-score between 0.60 and 0.70. This index is important also for local government in Europe, because it indicates, that no matter the differences, people for the most part well of. There are hardly problems with illiteracy or finding well-educated people to do the job in local government and there are financial resources to fund the activities of local government.

\section{Local Government Differences in General}

As told above, the vast majority of European countries are member of the Council of Europe. Its Charter denotes the main principles of local governance in Europe that are expected to be respected by all signatures. Because of the crucial importance of the contents of the Charter (describing agreed contextual values about local democracy in Europe) we will first provide the short review of the core principles of the Charter. It first describes the principle of local self-government which should be recognized in domestic regulation, and where practicable in the constitution (Article 2). It also stipulates the right and the ability of local authorities, within the limits of the law, to regulate and manage a substantial share of public affairs under their own responsibility and in the interests of the local population (Article 3). Furthermore, local governments should have full discretion to exercise their initiative with regard to any matter, which is not excluded from their competence nor assigned, to any other authority. Public responsibilities shall generally be exercised, in preference, by those authorities, which are closest to the 
citizen. Local authorities shall be consulted, insofar as possible, in due time and in an appropriate way in the planning and decision-making processes for all matters which concern them directly (Article 4). Local authorities shall be able to determine their own internal administrative structures in order to adapt them to local needs and ensure effective management. The conditions of service of local government employees shall be such as to permit the recruitment of high-quality staff on the basis of merit and competence; to this end adequate training opportunities, remuneration and career prospects shall be provided (Article 6). Local authorities shall be entitled, within national economic policy, to adequate financial resources of their own, of which they may dispose freely within the framework of their powers (Article 9). They have the right to associate with other local authorities in order to carry out tasks of common interest (Article 10) and they are to be legally protected (Article 11).

Under such a comprehensive common unifying structure one might expect that local government structures in Europe would not diverge significantly from the point of view of structural and human resource conditions, but this is not the case in Europe. We provide some dimensions of such divergence in the next paragraphs.

In financial terms - the level of decentralization measured in expenditures of local governments - these are in the EU on average about 12-13 per cent of GDP (2010), which is about half of the expenditures by national governments. However, even the EU is not a homogeneous entity with regard to the autonomy of local governments. In its North western part, the role of local governments is significantly more important than in the southern part. For instance, the expenditures of local government in Denmark, Sweden and Finland are all above 20 per cent of GDP, while this is less than 10 per cent in Belgium, Greece, Spain, Portugal, Austria, Slovakia, Bulgaria, and Germany (Eurostat). The situation in non-EU members from the point of view of subnational expenditures is rather critical (except for reach non EU states like Switzerland and Norway) - own revenues of local self-governments plus lump sum transfers are insufficient to cover own responsibilities and local expenditures represent very small proportion of GDP. The most critical case is Belarus, where real subnational finance do not exist.

The share of local expenditures to GDP is only one indicator for local autonomy. Another one is the ability of local government to raise its own revenues. Here also huge differences are visible in Europe. Especially in Eastern European countries, but also in a western European country as The Netherlands, local authorities are not, or only to a minor degree, allowed to collect their own revenues through local taxes and they are dependent on transfers from national government, which are provided in terms of general transfers and specific transfers. In the latter case, local governments can only use the money for policies specified by national government. Some have said that this [3, p. 29].

A third point of difference lies in the tasks of local governments and the actual service delivery under their responsibility. Local communal services are obvious local responsibility, but in many countries, for example, health care or primary education is not local but state responsibility. Countries differ to the extent to which national of 
subnational governments are responsible for education, health-services, housing, infrastructure, local economic development, the provision of welfare, public order and safety, social integration, culture and recreation, and sports, to mention just some of the policy areas in which local authorities could be autonomous. The tasks decentralized to municipalities in a majority of European countries concern basic education, sports, social services, urban planning, local infrastructure, culture, environment, water supply, public transport, waste management, and to a lesser extent (parts of) health care, housing, local economic development, sewage and public order and safety [2, own calculations].

Special cases are the United Kingdom and Ireland (the same principle is applied also in Ukraine, but for other reasons). Because of historical tradition, local selfgovernments' rights are still formally restricted by the "ultra vires" principle, telling that they must have statutory authority for everything they do (this means they can execute only functions allocated to them directly by law). Such a situation is formally contradictory to the Charter, telling that local authorities shall, within the limits of the law, have full discretion to exercise their initiative with regard to any matter which is not excluded from their competence nor assigned to any other authority. The Charter says in simplified way - "what is not prohibited is allowed", but the "ultra vires" principle is based on the assumption that "what is not allowed is prohibited". In real life, also because of local and Congress pressures, the "ultra vires" principle is today more a formal than a real problem - it does not seem to limit independent decision making of local self-governments in United Kingdom and Ireland too much.

Differences also exist within countries, when large cities and metropolitan areas have much more autonomy and responsibilities than small municipalities. This is, for instance, the case in Albania, Croatia, Cyprus, Estonia, Macedonia, Georgia, Germany, Hungary, Ireland, Latvia, Poland, Portugal, Romania, Serbia, Slovakia, Spain, Turkey, Ukraine, and the UK [2]. Size matters and differs within and among countries.

Probably the most interesting and differentiating issue in Europe is the size of local self-governments. Existing data (especially reports of the Congress and Moreno et al, 2012) indicate that there is no relation between the size of a country (both from the point of view of the number of inhabitants and the size of territory) and the level of the territorial fragmentation. Many European countries are characterized by a high level of territorial fragmentation and especially the existence of really small municipalities. Illustrative cases are Armenia with the smallest municipality consisting of 37 inhabitants and Herstappe in Belgium with about 87 inhabitants. Also worth mentioning in this regard are the Czech Republic with more than 6000 municipalities per 10 million inhabitants and Slovakia with almost 3000 municipalities per 5,5 million inhabitants.

On the other hand, Europe counts 71 metropolitan areas with more than half a million inhabitants [6], including Moscow (15 million inhabitants), Paris (11 million) and London with 10 million inhabitants. According to Warner [19], suboptimal local government size raises two concerns: 1) capacity - small size can lead to inadequate 
financial or managerial capacity and 2) fragmentation - lacking economies of scale undermine efficiency. She concludes that the smallest governments are least attractive and least able to play effectively and efficiently in market systems for public service delivery. This denies many rural areas the opportunity to effectively explore the benefits of service delivery innovation. At the metropolitan regional scale, the problem of suboptimal government size is the problem of fragmentation and the inability to coordinate and finance service delivery across the metropolitan region.

\section{The Internal Structure of Local Government: Commonalities and Differences}

In general, a local government consists of a political part, including a council and a mayor, and an administrative body, where the administrators conduct their work. However, that is where the similarities end. In some countries the mayor is elected through direct elections (f.i. Bosnia, Croatia, Poland, Slovakia), in others he or she is elected/appointed by the local council (f.i. Denmark, Czech Republic, Estonia, Georgia, Germany, Spain), and in still others he or she is appointed by higher authorities (f.i. Netherlands, parts of Belgium). In addition, the period for which the election/ appointment is valid, varies between one year (in Ireland) and six years (in for instance Netherlands). Most frequent is a four-year period. Sometimes, as in Austria and Belgium, procedures even vary within the country.

Although one might think the mayor to be the most important office in local government, this is not the general case. The role of the mayor is sometimes limited to a purely symbolic one, often limited to chairing the local council, sometimes responsible for public order and safety, and often he or she is the head of the administration and responsible for the internal organization of the municipality. However, for example in Ukraine or Moldova, the mayor is - according to the law the highest executive level of the local self-government.

For most countries the main "legislative" local self-government bodies are the elected assemblies, that is, local councils. The supreme power in a municipality does not lie in the mayor's office, but in the local council, which in Europe is nearly always democratically elected by universal suffrage (in some countries proportional system applies - f.e. Moldova). Specific problem is the local government in the capital of Azerbaijan - Baku. The Council of Europe severely criticized this country by recommending it to: "recognize municipalities as decentralized institutions exercising public power as part of the overall public administration, reconsider substantially and clarify the division of tasks and powers between parallel structures of local public administration, transferring the most important local public competences to municipalities and allocate sustainable financial resources to municipalities, commensurate with their competences, and ensure that municipalities can freely dispose of their resources within the scope of their powers. Finally, the Congress calls on the Azerbaijani authorities to enact a law on the special status of the capital, Baku, to consider providing a system of democratic election for the local government of Baku city." (Council of Europe, $23^{\text {rd }}$ session, Feb. 2013) 


\section{Explanations for the Variance in Europe's Local Government Conditions}

The analysis above indicates on the one hand a common framework, as laid down in the charter of the Council of Europe, which all member countries have ratified (some of them with reservations). On the other hand huge differences are seen in the institutional and organizational structures. Partly these differences can be explained by the national context in which municipalities function. The distinct features membership of the EU, wealth and human development - can explain part of the variance. Some scholars tend to explain the variance by cultural differences, mainly in terms of religion - the Protestant North versus the Catholic South and the more Orthodox east. Others see a lasting historical influence of the Napoleonic conquests, which introduced centralization and limited the powers of previously autonomous cities in the countries conquered by France around the turn of the $18^{\text {th }}$ and $19^{\text {th }}$ century. Goldsmith and Page suggested an explanation in a combination of geographical factors, democratic legacy, economic development, and path dependencies [11].

Especially the case of the United Kingdom and Ireland indicates that path dependence plays an important role. The "ultra vires" principle, mentioned above, is the "non-written" source of the legislation and it is very difficult to depart from it. Path dependence may also influence the level of fragmentation or levels of the administrative oversight over self-governments (countries with strong central state tradition are less ready to trust to capacities of self-governments and to the principle of subsidiarity.

Interesting cases are transition countries. In theory, during the transformation from centralistic to democratic structures, starting nearly much from "zero", these countries got the opportunity to introduce optimum solutions and optimum models (however, in reality many obvious optimum solutions do not exist). Interestingly, politics, power play and defending vested interests, seems to be the main determinant of the processes of transformation in this region. The most visible case is the creation of regional structures - established not in the first phase of transformation, but often as part of the EU accession process. The dominance of political arguments over rational arguments express themselves, for instance, in the outcomes of political decisions on decentralization, the creation of subnational units and their functions, and for instance, reforms in local government, such as amalgamations.

For instance, if we just look at new EU member states in Central Europe, we see that Bulgaria with 7.5 million inhabitants created 28 regions, Czech Republic with 10.5 million inhabitants now has 14 regions, Hungary with 10 million inhabitants has 23 regions and Poland with 38 million inhabitants has 16 regions. It is visible that other than "factual" factors determined new territorial structures in these countries.

In addition, the vast differences in tasks allocated to local governments vary not because public choice theory and research tells that some policy areas are better taken care of at the local level and others fare better when under the responsibility of 
national government. Rather, political interests and conflicts seem to determine the outcomes of such processes.

The same goes for decisions about at present popular municipal amalgamations. The process is full of conflict, ideology, fear, and negative side effects. First, many of the arguments used by policy makers in support of amalgamations just reflect ideological framing as opposed to genuine reasons for amalgamation [cf. 5].

\section{Summarizing the Context of European Local Government}

The above suggests that local government in Europe on the one hand performs within a rather specific context, certainly in comparison to other regions in the world. There is a clear legal framework for local government - ratified by most of the European countries and based on the subsidiarity principle - that assures a substantial role for local government as well as legal protection and its ability to recruit highquality staff based on merit and competence. Furthermore, the majority of European countries are relatively wealthy and the population enjoys a high to almost maximum human development. All this is favorable for the position of local government in Europe.

Because of path dependencies, historical and cultural factors, the division among EU-membership lines and the dominance of strategic instead of substantial arguments, but also because some questions do not have definite answers (like fragmentation versus amalgamation), one can still witness huge differences in the structure, the autonomy and responsibilities of local governments as well as in their position vis-à-vis higher authorities. The question is how these differences impact on the opportunities and challenges local governments in Europe face. The next section will address the main challenges of local government in Europe and will argue that the degree to which these varying contexts affect the current issues regarding local government capacity can be relativized.

\section{Issues of Local Government Capacity in Europe}

How do local governments in Europe perform? This section addresses that question. First we give an overview of the scarce data on satisfaction of citizens about their city administration and their opinion about the situation in these cities. These data are derived from the Urban Audit, a project conducted on behalf of the European Commission, monitoring how citizens perceive quality of life in their home cities. In 2012, 41.000 people were interviewed in 79 European cities and 4 urban agglomerations. One of the questions related to the quality of administrative services in these cities. In 53 of the cities surveyed, a majority of respondents consider that their city's administrative services help people efficiently. In 7 cities, the level of agreement equals or exceeds 70\%. Luxembourg (77\%), Aalborg, Antwerp and Zurich (all 72\%) have the highest level of agreement, while Palermo (17\%), Napoli (19\%), Roma (21\%) and Bratislava (28\%) have the lowest. In 67 cities, a majority of respondents consider that their city's administrative services can be trusted, and in 21 
cities at least $70 \%$ of respondents share the same view. A majority of respondents agree with this statement in 67 out of the 83 cities surveyed, and in 12 cities, at least three quarters of them agree. Luxembourg, Zurich (both 87\%), Aalborg (83\%) and Munich (81\%) recorded the highest scores for this question (ibid, p98), while Palermo (24\%), Prague (28\%), Bratislava and Napoli (both 29\%) have the lowest [7, p. 12].

The satisfaction with regard to public spaces such as markets, squares and pedestrian zones, their satisfaction regarding the availability of retail shops and green spaces, and the perception of safety is high. In all but one city, a large majority of respondents says they are satisfied with the lives they lead; and a majority of respondents is satisfied with the place where they live. The satisfaction with schools and educational establishments and the satisfaction regarding the state of streets and buildings in respondents' neighborhoods is somewhat lower (p. 9), although in most cities, still a majority of the respondents that have an opinion about such things, are satisfied.

Within European cities, the citizens seem to have good life and they are in general satisfied with the performance of the municipal administration. The differences in opinion reflect especially the North-South difference, that is, the level of decentralization, and the West-East difference, that is the level of national wealth [cf. 5]. In countries where the share of public expenditures by local governments is higher, the citizens are also more satisfied about local governments' accomplishments, as is the case in relatively wealthy countries compared to the less well-off countries.

Hence, the main challenges are not to be found in the for Europe favorable contextual conditions such as the political or judicial situation, the socio-economic situation of the country involved, historical determinants, et cetera, although the concrete country conditions might explain part of the variance in local government performance. Nor are the main challenges likely to be found in human resource conditions, referring, to illiteracy or lacking capability of local government leadership, or the absence of skills in the administration.

Political and socio-economic situation in the country may but must not influence the performance of local governments, depending on local conditions. Decentralization and the principle of subsidiarity are very much based on assumption of vital local democracy and high level of participation of citizen in local issues. However, this is not really true for all European countries, with positive and negative examples both in "East" and "West" or "North" and "South". Challenges in the "East" may be partly "historical" - citizens in transitional countries are still not well prepared to effectively control politicians and bureaucrats (neither on central, nor on local level) - which is hardly a surprise after the long period of former regime. Many, especially older people, still think that the state "donates them its services" and they must be satisfied with any quality provided.

Currently the core challenges are mainly structural and institutional - elaborated on below. First we address the new trend in Europe from decentralization towards 
centralization, second, the trend to consolidate local governments, and third, the growing financial problems of local governments.

\section{From Decentralization to Centralization}

As to the intergovernmental relations between local and national government the challenge is situated especially in the continuing changes in the relation, from centralization to decentralization and recently back again [cf. 4; 13]. From the 1980s onwards to the middle of the first decade of the new millennium, there were widespread trends of decentralizing powers and authority to the subnational, especially local level.

Since 2005 a reversal of this trend is seen, especially in those countries that decentralized the most, be it out of New Public Management ideas, or because of external pressures to do so, like in the transition countries and Turkey, for whom it was a requirement to become members of the EU [13]. In 2004, this incentive ended for the 10 Central European countries, who did indeed become EU-members, while in Turkey it became apparent around 2010 that the EU became too hesitant in accepting its membership.

The consequence was that decentralization-processes ended and reversed in processes of re-centralization. Those countries which were decentralized furthest out of NPM ideas, like the UK, started so-called joined-up government, partly because of the frustration of central government that it had lost its capacity to act as a coordinated, single actor, out of which attempts to strengthen policy capacity of the center emerged [Halligan, in: 13]. The countries involved, achieved this re-centering by 1) implementing institutional and procedural measures to increase horizontal coordination, for instance tightening legal frameworks, limiting the discretionary powers of local governments, and through intersectoral policy programs in Finland, or the creation of a Prime Minister's Delivery Unit in England, 2) a shift from letting-go strategies to a restoring strategy in which especially the prime-minister's office is increasing its political control, and 3) by increasing the audit capabilities out of visions of strategic management, coordination and vertical coordination. Peters et al (2011, introduction) conclude: "many presidents and prime ministers are attempting to find ways of restoring their capacity to govern from the center".

The Anglo-Saxon and Scandinavian countries are not the only ones in which recentralization is visible. According to the German Reinhold Schnabel more and more people are criticizing the concept of federalism, asking whether the system has become outdated. For these critics, the structure of 16 federal states, with 16 state parliaments, and 16 state governments with their dozens of ministers, state agencies and thousands of officials has become an unaffordable model. In Germany in 2005, the Federal State ordered tax equalization as well as limits on state borrowing,

Gellén [9] mentions similar tendencies in Hungary and describes these reformsteps by the labels of concentration and centralization affecting the entire corpus of administration. On January $1^{\text {st }} 2013$ Hungarian central government took over the responsibility for schools from local self-governing authorities. Saltman [15] gives a 
nice overview how the tendency to decentralize health care has seen a reversal from the early 2000s onwards, first in Scandinavia, but later on also in Germany, Netherlands and Poland. Pola [14] describes similar tendencies in France and Italy, and the most striking example is of course Russia under Putin $[10 ; 16]$. The latter argues that in Russia one can witness "significant strengthening of presidential power and its expansion to a regional level through a new institution of Plenipotentiary Representatives of the President of the Russian Federation established in eight federal districts". Furthermore, "the proposed direct election of governors was annihilated. Today governors are elected by local parliaments, and candidates are those as advised by the President". Seliverstov and Leksin conclude; "It is clear that in recent years we have witnessed a noticeable strengthening of central power in its relationship with the regions. This was reflected in the formation and strengthening of the vertical, as well as in a whole set of measures associated with the concentration of political and economic powers in the presidency and the federal government." [16, p. 141].

\section{Consolidating Local Government}

A second trend, affecting institutional conditions witnessed in Europe, is the tendency to consolidate subnational government [cf. 5]. First, in Scandinavian countries, Denmark decreased the number of municipalities from 275 to 98 between 2000 and 2010; Finland went from 436 to 342; and Iceland from 124 to 77. In Western Europe, the process of consolidation also continues. The Dutch continue incremental amalgamation to a current number of 400 municipalities, compared to 500 in the early 2000 s, and it plans to reduce the number of municipalities to no more than 150 during the second half of this decade. Within roughly the same period, the 12 provinces will be reduced to five counties. Ireland plans to consolidate local government and reduce the number of regions from eight to three. In 2012, Turkey, with a population of approximately 74 million, decreased the number of municipalities from 2950 to 1375 . In Greece, the 1997 Capodistrias Plan reduced the number of municipalities from 5825 to 1033 , although its original plan was to end up with 500 municipalities.

Turning to Central and Eastern Europe, in 2004, Macedonia reduced the number of municipalities from 123 to 84 based on the Ohrid Framework Agreement. Georgia reduced the number of local governments from 998 to 64 in 2006 after the Rose revolution. Beginning in 1998, Latvia encouraged local governments to amalgamate with the intent to reduce the number of local governments from 542 to 102 . No local government would have a population under 4,500 and the average would have to rise to about 23,000 people [8, p. 7].

In other countries, amalgamations are on hold, but the autonomy of small communities is nevertheless reduced by the required intensified cooperation between them or between them and a central city. This happened in Hungary, where the government introduced "multipurpose micro-regional associations", which can comprise up to 65 municipalities around a larger town. It is also evident in the Czech 
Republic where municipalities cooperate intensively, especially in the areas of regional development, tourism and environmental protection, and somewhat less in social infrastructure, energy, transport and waste disposal, and in order to receive European subsidies [18]. The only country with clear plans to increase the number of municipalities was Lithuania. This plan was a result of the substantial amalgamation activity in the 1990s that reduced the number from 581 to 56 . This process created municipalities that were too large according to the Lithuanian government [cf. 5] - in 2015 also Georgia started to return back by increasing number of local units, officially on the base of the same argument.

\section{The Problematic Financial Situation of Local Governments in Europe}

The third major challenge for local governments is posed by their financial situation. Only looking at the European Union, the total local government debt is estimated to be around 1 trillion US \$, or about $6 \%$ of total GDP. In all countries, the municipal debt sharply increased between 2007 and 2010 (Table 1). Especially in countries like Spain, Germany, Turkey and Ireland the situation is becoming grave as municipal debt is nowadays higher than the yearly local revenues and the increase in debt during the crisis is sharply increasing. In Spain, debt doubled in four years, as it did in Slovenia and Bulgaria (In the latter two cases the increase came from a minimum base).

Apart from Moldova, Russia and Bulgaria in all countries the municipal debt is higher than $25 \%$ of local revenues (Table 2). If the "critical" level is somewhere between $50-100 \%$, depending on the concrete situation, the problem is pressing in at least four countries. In absolute values, according to the most recent statistics, taking Germany ( 80 million inhabitants), the total municipal debt is about 135 billion Euros and in Netherlands (16 million inhabitants), the municipal debt is 51 billion Euros in mid-2013.

In Finland, local authorities nowadays hold 70 per cent of all public debts. Of course, there are differences in the debt problem even when the local finance systems - with regard to deregulated local borrowing- are similar. (For example no increase is seen in the Czech Republic compared to massive increase in local debt in Latvia). 
Table 1. Local government debt as per cent of GDP (top to down)

\begin{tabular}{|c|c|c|c|c|c|}
\hline Country & 2007 & 2008 & 2009 & 2010 & $\begin{array}{l}\text { Increase during the crisis } \\
(2010 / 2008)\end{array}$ \\
\hline Norway & 9.6 & 9.8 & 11.7 & 12.6 & 29 \\
\hline Netherlands & 7.1 & 7.3 & 8.0 & 8.4 & 15 \\
\hline France & 7.2 & 7.5 & 8.2 & 8.3 & 11 \\
\hline Italy & 8.0 & 8.1 & 8.6 & 8.3 & 2 \\
\hline Denmark & 6.3 & 6.6 & 7.3 & 7.2 & 9 \\
\hline Finland & 5.3 & 5.4 & 6.6 & 6.6 & 22 \\
\hline Latvia & 3.3 & 4.1 & 5.8 & 6.4 & 56 \\
\hline Sweden & 5.6 & 5.5 & 5.5 & 5.6 & 2 \\
\hline Portugal & 4.2 & 4.5 & 5.1 & 5.2 & 16 \\
\hline Germany & 4.9 & 4.8 & 5.2 & 5.2 & 8 \\
\hline Belgium & 5.0 & 4.8 & 4.8 & 5.1 & 6 \\
\hline U. Kingdom & 4.6 & 4.7 & 4.8 & 4.9 & 4 \\
\hline Hungary & 3.1 & 3.9 & 4.1 & 4.6 & 18 \\
\hline Poland & 2.2 & 2.3 & 3.0 & 3.9 & 70 \\
\hline Estonia & 2.7 & 3.2 & 4.0 & 3.7 & 16 \\
\hline Ireland & 2.5 & 3.0 & 3.6 & 3.6 & 20 \\
\hline Spain & 2.8 & 2.9 & 3.3 & 3.3 & 14 \\
\hline Austria & 1.9 & 1.9 & 2.3 & 2.8 & 47 \\
\hline Slovakia & 1.8 & 1.9 & 2.4 & 2.7 & 42 \\
\hline Czech R. & 2.5 & 2.5 & 2.7 & 2.6 & 4 \\
\hline Romania & 1.7 & 1.9 & 2.3 & 2.4 & 26 \\
\hline Luxembourg & 2.2 & 2.2 & 2.3 & 2.3 & 5 \\
\hline Cyprus & 2.0 & 1.9 & 2.0 & 2.0 & 5 \\
\hline Slovenia & 0.7 & 0.9 & 1.5 & 1.7 & 89 \\
\hline Lithuania & 1.0 & 1.2 & 1.6 & 1.6 & 33 \\
\hline Bulgaria & 0.6 & 0.6 & 1.0 & 1.2 & 100 \\
\hline Greece & 0.8 & 0.8 & 0.9 & 0.9 & 13 \\
\hline EU 27 & 5.1 & 5.1 & 5.7 & 5.8 & 14 \\
\hline Euro area 16 & 5.5 & 5.6 & 6.1 & 6.1 & 9 \\
\hline
\end{tabular}

Source: Urban Audit Database Eurostat

Partly this situation is due to the international crisis by which transfers from national governments to local governments diminished. On the other hand, central governments diminished the discretionary powers of local governments, thus reducing their possibilities to adapt to the changing financial circumstances. Local governments became less able to change policies (and the expenditures involved), because of increased restrictions in national legal frameworks. 
Table 2. Local government debt as per cent of total local revenues (all tiers combined, top to down: 2008)

\begin{tabular}{|l|c|c|c|}
\hline Country & $\mathbf{2 0 0 8}$ & $\mathbf{2 0 0 9}$ & $\mathbf{2 0 1 0}$ \\
\hline Spain & 169.7 & 182.5 & over 220 \\
\hline Germany & 153.0 & 171.7 & 187.4 \\
\hline Turkey & 120.8 & 126.0 & 127.0 \\
\hline Ireland & 100.0 & 114.0 & n.a. \\
\hline Sweden & 46.3 & 50.5 & 45.8 \\
\hline Latvia & 39.7 & 57.0 & 62.0 \\
\hline Estonia & 37.7 & 45.9 & 44.8 \\
\hline Hungary & 32.2 & 36.6 & 43.3 \\
\hline Croatia & 29.1 & 32.2 & 30.2 \\
\hline Denmark & 29.3 & 29.3 & n.a. \\
\hline Slovakia & 26.7 & 31.8 & 38.4 \\
\hline Czech Republic & 24.5 & 26.2 & 24.7 \\
\hline Finland & 22.4 & 23.8 & 23.2 \\
\hline Romania & 21.8 & 26.0 & 27.1 \\
\hline Poland & 20.3 & 26.0 & 33.8 \\
\hline Slovenia & 15.9 & 22.4 & 25.4 \\
\hline Moldova & 6.4 & 5.0 & 4.0 \\
\hline Russia & 6.1 & 7.6 & 8.0 \\
\hline
\end{tabular}

Source: Urban Audit Database Eurostat

The consequence is that many a municipality has to take action in order to reduce their financial problems. As a recent Ernst \& Young report notes about Germany, "Given the desperate financial situation of many municipalities comes another wave of power cuts and tax increases on the citizens: three-quarters of local authorities want to increase 2013/2014 taxes and fees. And 37 per cent plan to reduce or discontinue services, such as street lighting in the area or in child and eldercare." [cf. $1]$.

\section{Implications}

What does all the above imply for the position and challenges faced by local governments in Europe? Below we give a framework analysis of the pros and cons of the situation of local governments in Europe.

First we are able to conclude that the main strength of Europe is the existence of strong and consolidated local self-government systems (except for very few countries) that exercise significant levels of trust by local inhabitants (especially in Nordic countries) and deliver high quality local public services. Another strength is the fact that local government systems in Europe develop according to centrally expressed and supervised principles of local self-government that are formulated by the European Charter for Local Self Government in a comprehensive way. 
The strong development of local and regional democracy in Europe is protected and based on the principles of the Charter of the Council of Local and Regional Authorities of the Council of Europe (CLRAE). Among its many activities, CLRAE regularly organizes monitoring visits to all member states to check the situation of local and regional democracy. These visits are an important and effective tool to motivate all European governments to strengthen local democracy based on the principles of the Charter. The contents of all monitoring reports (available on line) indicate that member states devote more and more attention to issues raised in such monitoring reports and tend to act accordingly. Another favorable condition for most of the region is the relatively high level of the economic and human development.

It is difficult to define common weaknesses of the local democracy in Europe. However, we need to mention the core structural challenges here, for instance the continuous discussion about amalgamation versus fragmentation. The existence of too many, too small municipalities with limited human and financial capacities to deliver local public services in some countries presents a limitation to effective and efficient local service delivery. The trade-offs between fragmentation and consolidation are frequently debated in scholarly research. Whereas consolidation of municipalities is mainly favored for its supposed impact on adequate service delivery, the basic argument for smaller local units relates to local democracy - the idea of localism and the idea of public choice. Although the ideas of localism and public choice are based on very different theoretical assumptions, both arrive at the similar conclusion that "small is beautiful". The most important arguments for territorial consolidation are connected with theories on the economies of scale. According to such theories the small size of municipalities (including a lack of finance and employment opportunities for their inhabitants, a lack of technical infrastructure, difficult access to basic services and small population) limits their performance. In reality, the issue of the optimum size of municipalities is much more complicated and politically very sensitive.

Most countries indicate one overarching threat to the local democracy in Europe today, that is, the financial crisis, which significantly decreased the level of available financial resources for self-governments, while the structure of responsibilities remains the same or even increases and the demands certainly increase. Some CLRAE delegations complain that the level of budget cuts at the local and regional level is proportionally higher compared to cuts at the central level, which may result in too limited resources and subsequently decreased service delivery standards and cuts of some local services (for example some cities in Ireland already fully privatized communal waste management). Financial burdens are also increased by the trend towards outsourcing and public private partnerships, while many a local government lacks knowledge, experience, and capacity in public procurement, making the outcomes of such processes more expensive than needed.

A second core threat visible in many European countries is the trend toward recentralization (plus limited real will do continue with decentralization, respecting CLRAE recommendations), including limitations on local policy discretion by 
national regulations and the reduction of local powers and authorities in many a policy area.

Regional issues differ, and we mentioned the situation of post-communist countries, where local democracy does not have a long tradition and still needs to be revitalized. The second clear regional challenge is the situation in some CIS countries, where central governments are not at all inclined to promote the idea of decentralization (especially Azerbaijan and Belarus).

\section{Conclusion}

1. This article argued that the local government capacities and local government performance in Europe clearly rank this continent to the most developed world areas from the point of local democracy. The background factors explaining this situation have a multidimensional character and one can identify as core positive factors the relative economic wealth, high human development, the long historical tradition of the subsidiarity principle in most parts of Europe, and the regulatory function of the Council of Europe. However, this does not mean that everything is perfect in Europe and that there would be no challenges to be addressed.

2. The core challenges to be addressed from the international perspective have regional dimensions. They are seen in the varying development of local democracy, especially along the East West continuum and the varying development of local autonomy, especially along the North-South continuum.

3. For instance along the East-West continuum one sees the specific challenges of several post-communist countries compared to the more optimal situation of local governments within the old EU-member states. Most improvement and assistance are needed in those countries where self-government structures are still weak or in early phases of their development - parts of the Balkan area, Moldova, Ukraine and Caucasus. Taking the strong position of CLRAE into account, the coordination of such assistance and training within CLRAE activities could avoid any potential conflicts and problems.

4. The North-South dimension still represents the division between more and less developed subsidiarity and varying trust in strong local autonomy. In the northern part of Europe local governments are responsible for more policy areas and their part in the public expenditures are significantly higher than in Southern Europe. However, the trend seen is that in especially in the North, national financial problems are partially transferred to the local level by decentralizing policies without providing the necessary financial means, and simultaneously limiting municipalities in their policy discretion by national regulations, and thus also limiting the possibilities of municipalities to address their financial problems.

5. Concluding, this article argues that currently the main challenges for local government in Europe are structural and institutional, in terms of horizontal and vertical intergovernmental relations. The new trends in Europe initiated mainly by national governments, from decentralization towards re-centralization, the growing 
financial problems of local governments and the amalgamations, pose challenges difficult to address properly.

\section{References}

1. Armstrong, M. (2013). The European Debt Bomb - Unbelievable, August 22. http://armstrongeconomics.com/2013/08/22/the-european-debt-bomb-unbelievable/

2. CEMR. (2011). Council of European Municipalities and Regions. Local and regional government in Europe Structures and competences. www.ccre.org (accessed December $\left.1^{\text {st }}, 2013\right)$.

3. Dabla-Norris, E. and P. Wade. (2002). Production, Rent Seeking and Wealth Distribution. Washington DC. International Monetary Fund. IMF working paper 29.

4. De Vries, M. S. (2000). The rise and fall of decentralization: A comparative analysis of arguments and practices in European countries. European journal of political research, 38(2), 193-224.

5. De Vries, M.S. and I. Sobis. (2013). Consolidation in local government: An international comparison of arguments and practices. In: Administration: Journal of the Institute of Public Administration of Ireland: vol. 61, no. 3.

6. Demographia World Urban Areas. (2013). 9th Annual Edition. Available online: http://www.demographia.com/db-worldua.pdf (accessed on December, $1^{\text {st }}, 2013$ ).

7. European Commission. (2013). Urban Audit. European Commission, DG Regional Policy and Eurostat. Available: www.urbanaudit.org. (Accessed December $1^{\text {st }}, 2013$ ).

8. Fox, W., \& T. Gurley-Calvez. (2006). Will consolidation improve sub-national governments? World Bank Policy Research Working Paper, (3913).

9. Gellén, M. (2012). Does Centralization Serve Efficiency? De-Agencification in Hungary. NISPAcee Journal of Public Administration and Policy, 5(2), 67-87.

10. Gel'man, V., \& T. Lankina. (2008). Authoritarian versus democratic diffusions: explaining institutional choices in Russia's local government. Post-Soviet Affairs, 24(1), 40-62.

11. Goldsmith, M., \& E. Page. (Eds.). (1987). Central and local government relations: $a$ comparative analysis of West European unitary states. Sage Publications.

12. Moreno, A. M. (ed). (2012). Local government in the member states of the European Union: a comparative perspective. Madrid: INAP

13. Peters, B. G., C. Dahlström, C., \& J. Pierre. (Eds). (2011). Steering from the Centre: Strengthening political control in western democracies. University of Toronto Press.

14. Pola, G. (2010). 1948-2008: The Ups And Downs of a 60-years-long decentralization process In Italy. IAFCS conference. Decentralizing and Re-centralizing Trends in the Distribution of Powers within Federal Countries. 2008, Barcelona, September 19-20, 121-140.

15. Saltman, R. B. (2008). Decentralization, re-centralization and future European health policy. The European Journal of Public Health, 18(2), 104-106.

16. Seliverstov, V. and V. Leksin. (2010). Present Centralization in Russian Federalism: Economic Effects and Interactions. In: IAFCS conference. Decentralizing and Re- 
centralizing Trends in the Distribution of Powers within Federal Countries. 2008, Barcelona, September 19-20, 141-155.

17. UNDP, 2014

18. Vajdova, Z. and D. Čermak (2006). Uzemni změny obci v ČR od roku. 1990. (Territorial changes of municipalities in the Czech Republic since 1990). In: Z. Vajdova, D. Čermak, and M. Illner (eds.) Autonomie a spoluprace: di̊sledky ustaveni obecniho zrrizeni v roce 1990 (Autonomy and Cooperation: Impacts of the Municipal System of 1990). Prague: Institute of Sociology ASCR, Sociological Studies 6(2), 27-37.

19. Warner, M. E. (2012). Privatization and urban governance: The continuing challenges of efficiency, voice and integration. Cities (29), 38-43.

Juraj Nemec, Michiel S de Vries

\section{Vietos valdžios struktūra ir gebėjimai Europoje}

Anotacija

Straipsnyje įrodoma, jog vietos valdžios gebėjimai ir veiklumas Europoje leidžia aiškiai laikyti ši žemyną kaip labiausiai pažengusị vietos savialdos srityje. Kontekstiniai veiksniai, paaiškinantys šią situaciją, yra daugiadimensiniai - kaip esminius teigiamus veiksnius galima išskirti santykinę ekonominę gerovę, aukštą žmogaus raidos indeksą, ilgą istorinę subsidiarumo principo daugelyje Europos šalių tradiciją ir reguliacinę Europos Tarybos funkciją. Nuoseklus vietos ir regioninès demokratijos Europoje vystymasis yra ginamas ir grindžiamas Europos Tarybos priimtoje Europos vietos savivaldos chartijos principais. Europos Taryba, be daugelio kitų veiklų, reguliariai vykdo stebėsenos vizitus ị visa šalis nares, kurių metu tikrina vietos ir regioninès demokratijos situaciją. Šie vizitai yra svarbi ir efektyvi visų Europos šalių vyriausybių motyvavimo stiprinti Chartijos principais pagrįstą vietos demokratiją priemonè. Tačiau tai nereiškia, jog Europoje viskas tobula ir kad nèra jokių iššūkių, ị kuriuos reikètų reaguoti. Yra sunku aiškiai apibrèžti bendrus vietos demokratijos trūkumus Europoje. Tačiau reikia paminèti, jog kaip vieną esminių struktūrinių iššūkių galima išskirti nepertraukiamą diskusiją apie suvienijimą versus fragmentaciją. Dauguma šalių kaip vieną svarbiausių grèsmių vietos demokratijai šiandienos Europoje nurodo finansinę krizę, kuri žymiai sumažino vietos valdžiai prieinamų finansinių išteklių lygį, nors atsakomybẻ išlieka tokia pati ar net didesnè, tuo pačiu neabejotinai didèja ir poreikiai. Kita daugumoje Europos šalių pastebima esminè grèsmè yra recentralizacijos arba ribotos valios tęsti decentralizaciją tiek išsivysčiusiose, tiek besivystančiose demokratijose, tendencija. Regioninès problemos yra skirtingos, ypač situacija pokomunistinèse šalyse, neturinčiose ilgos vietos demokratijos tradicijos, kuri turi būti gaivinama iš naujo. Dar daugiau, centrinė valdžia kai kuriose NVS šalyse visiškai nèra linkusi propaguoti decentralizacijos idejją kaip oficialią nacionalinę politiką (ypač Baltarusija ir Azerbaidžanas).

Juraj Nemec - Professor, Dr. at the Department of Public Economics, Faculty of Ecomonics and Administration, Masaryk University, Brno, Czech Republic

E-mail.: Juraj.Nemec @econ.muni.cz

Michiel $S$ de Vries - holds the chair in Public Administration at the Radboud University of Nijmegen and is visiting professor at the Masaryk University; President of the International Association of Schools and Institutes of Administration (IASIA) 
E-mail.: m.devries@fm.ru.nl

Juraj Nemec - Masaryko universiteto Ekonomikos ir administravimo fakulteto Viešososios ekonomikos katedros profesorius.

E.paštas: Juraj.Nemec@econ.muni.cz

Michiel $S$ de Vries - Radboud Nijmegeno universiteto Nijmegen Viešojo administravimo katedros vedejjas, Masaryko universiteto vizituojantis profesorius, Tarptautinès administravimo mokyklų ir institute asociacijos (IASIA) prezidentas. E.paštas: m.devries@fm.ru.nl

Straipsnis įteiktas redakcijai 2015 m. rugpjūčio mèn.; recenzuotas; parengtas spaudai $2015 \mathrm{~m}$. rugsejo mèn. 